\title{
Progress in Australian dendroclimatology: Identifying growth limiting factors in four climate zones
}

Heather A. Haines ${ }^{a 1}$, Jon M. Olley ${ }^{a}$, Justine Kemp ${ }^{a}$, Nathan B. English ${ }^{b}$

a Australian Rivers Institute, Griffith University, 170 Kessels Road, Nathan, QLD, 4101, Australia

${ }^{\mathrm{b}}$ School of Medical and Applied Sciences, Central Queensland University, 538 Flinders Street West, Townsville, QLD, 4810, Australia

\footnotetext{
${ }^{1}$ Corresponding author. email address: h.haines@griffith.edu.au
} 


\section{Abstract:}

Dendroclimatology can be used to better understand past climate in regions such as Australia where instrumental and historical climate records are sparse and rarely extend beyond 100 years. Here we review 36 Australian dendroclimatic studies which cover the four major climate zones of Australia; temperate, arid, subtropical and tropical. We show that all of these zones contain tree and shrub species which have the potential to provide high quality records of past climate. Despite this potential only four dendroclimatic reconstructions have been published for Australia, one from each of the climate zones: A 3592 year temperature record for the SE-temperate zone, a 350 year rainfall record for the Western arid zone, a 140 year rainfall record for the northern tropics and a 146 year rainfall record for SE-subtropics. We report on the spatial distribution of tree-ring studies, the environmental variables identified as limiting tree growth in each study, and identify the key challenges in using tree-ring records for climate reconstruction in Australia. We show that many Australian species have yet to be tested for dendroclimatological potential, and that the application of newer techniques including isotopic analysis, carbon dating, wood density measurements, and anatomical analysis, combined with traditional ring-width measurements should enable more species in each of the climate zones to be used, and long-term climate records to be developed across the entire continent.

\section{Keywords:}

Australia; dendroclimatology; tree rings; climate change; paleoclimate 


\subsection{Introduction}

The Australian climate is amongst the most variable in the world with many areas of the continent experiencing prolonged periods of drought and above average rainfall (Pittock 2003; Peel et al., 2004; Gergis et al. 2012). Historic and instrumental records of both rainfall and temperature in most regions of the continent extend back less than 100 years (Bureau of Meteorology, 2001), and prior to 1910 there was no national network of climate observations. This makes assessments of the long-term significance of regional variations in rainfall and/or temperature difficult as these short records do not allow for the impact of lowfrequency phenomena on climate variability to be determined. These types of assessments can only be made using multi-centennial to millennial length rainfall and temperature records (see for example, Neukom and Gergis, 2012; Graham et al. 2007; Seager et al. 2007).

In North America and Europe, climate records have been extended beyond the start of instrumental and historical records using tree rings (Briffa et al., 1990; Cook et al., 2007; Luckman et al., 1997; Wilson and Luckman, 2005). In Australia, past reviews on the dendrochronological and/or dendroclimatological potential of Australian tree species have provided mixed views on the usefulness of this proxy for climate reconstructions (Ogden, 1978a; Worbes, 2002; Brookhouse, 2006). Many Australian species do not produce annual growth rings (Heinrich and Allen, 2013), exhibit ring wedging, false rings, and the growth patterns in many juvenile and dense understory trees are dominated by local factors rather than the regional environmental variables (Worbes, 2002). In addition, many Australian species are short-lived and suffer heartwood rot due to a shortage of nutrients and resources to support the large size of tropical trees (Ogden 1978a; 1981). As a result, potential records are short, and most parts of the continent lack depositional environments conducive to the preservation of ancient wood. Here we review 36 Australia-based dendroclimatology studies and summarize progress isolating climate relationships and the growth limiting factors in temperate, arid, tropical and subtropical environments. We report on the spatial distribution of tree-ring studies and identify the key challenges in using ring-records for 
climate reconstruction in Australia. We then discuss the potential role of dendroclimatology in the development of long-term paleoclimate records within Australia.

\subsection{Dendroclimatology}

Dendroclimatology is the reconstruction of variations in climate through time using several parameters from tree-rings including ring width, wood properties (being features that are represented annually in tree records but are independent of ring-width), and isotopic analysis. The starting point is to determine which environmental variable is the dominant factor limiting tree growth. Common climatic limiting factors are temperature, precipitation and/or moisture availability (Fritts, 1976). Careful site and tree selection is important to locate those trees which are growing at a threshold that would stress the tree so growth occurs when the intended climatic variable for reconstruction is at an optimum (Stokes and Smiley, 1968). For example, sites at high altitude or latitude where trees are stressed due to being at the threshold of their growth range provide the best temperature reconstructions (Brookhouse et al., 2008). Reconstructions of moisture availability and/or rainfall are often derived from trees on well drained slopes that rely on seasonal precipitation to promote growth. However, other non-climatic factors may limit growth, these include: canopy effects, chronic insect or fungal infestation, and/or frost season, among others. These localized effects can cause difficultly in extracting climate data from a tree-ring record (Davidson and Reid, 1985; Fritts, 1976; Morrow and LaMarche, 1978) and are more prevalent in some regions, such as the tropics (Ogden, 1978a).

The regional significance of the tree-ring record is established by crossdating patterns of ring growth within and between individual trees (Fritts, 1976). Crossdating is typically based on variations in ring-width which involves matching the pattern of ring-widths of different radii to create one overall pattern of ring-width variations through time for the site. Crossdating is first applied between several radii within a tree, and then between different trees within a 
group. The pattern created represents the fluctuations in the limiting environmental variable through time. Issues arise when there are localized influences on tree growth (eg insect infestation of an individual tree) but also from the nature of the wood itself. Ring boundaries can be difficult to identify due to faint banding, wedging/pinching rings, narrow ring series, missing rings due to harsh growth conditions, and false rings from variable climatic conditions, among others and this is especially prominent in certain environments such as tropical or arid regions (for details and images of these features see Speer, 2010: Figure 4.23). Care must be taken at this stage of analysis as it is normal for some trees to not be included in the final chronology due to a lack in crossdating. Once a series of trees have been crossdated they must be checked for quality and measurement accuracy allowing the researcher to determine if there are issues in the dating and work out the cause of any errors. A well crossdated set of tree-ring measurements can then be developed into a chronology for the tree/site/region. Several computer programs exist to assist for quality control and chronology which include, but are not limited to, COFECHA, ARSTAN, Tellervo, dpIR, WinDendro all of which have different advantages and disadvantages and are described in more detail elsewhere (see Cook, 1985; Guay et al., 1992; Grissino-Mayer, 2001; Bunn, 2008; 2010; Brewer, 2014). Once a chronology is developed several statistical tests are evaluated to determine the strength of the chronology such as the interseries correlation, mean sensitivity, and expressed population signal (EPS) among others. These statistics have threshold values that determine which portion of the record is statistically sound, for example an EPS value greater than 0.85 indicates a chronology is useful in representing climate (Wigley et al., 1986). The robust portion of the tree-ring chronology is then used to reconstruct the limiting environmental variable. This record is calibrated using an instrumental or proxy climate record that overlaps for at least a proportion of the time period. The overlapping portions of the two records, the tree-ring chronology and the measured data set, are divided into two, with one part used to establish the correlation and the other used to validate the calibration. When there are good results for both the statistical 
analysis of the calibration and validation phases of a proxy record a dendrochronological

climate reconstruction can be deemed representative of past climate conditions.

Table 1: Existing Australian tree ring chronologies by region and the potential climate related variable that could be reconstructed. Those shown in bold indicate studies for which a reconstruction was developed.

\begin{tabular}{|c|c|c|c|c|}
\hline \multirow[b]{2}{*}{ Region } & \multicolumn{4}{|c|}{ Environmental Variable with Potential for Reconstruction } \\
\hline & Temperature & Precipitation & Streamflow & SOI, IPO \\
\hline Temperate & $\begin{array}{l}\text { Allen et al., } 2011 \\
\text { (Athrotaxis sp.) } \\
\text { Allen et al., 2012 } \\
\text { (Athrotaxis cupressoides) } \\
\text { Pearman et al., 1976 } \\
\text { (Athrotaxis selaginoides) } \\
\text { Brookhouse, 2006; } \\
\text { Brookhouse and Brack, } \\
2006 \text { (Eucalyptus sp.) } \\
\text { Brookhouse and Bi, } \\
\text { 2009; Brookhouse et al., } \\
2008 \text { (Eucalyptus } \\
\text { pauciflora) } \\
\text { Allen et al., 2013; } \\
\text { Buckley et al., 1997; } \\
\text { Cook et al., 1991; 1992; } \\
\text { 1996; 2000; Drew et al., } \\
\text { 2013 (Lagarostrobos } \\
\text { franklinii) } \\
\text { Allen, 2002; Allen et al., } \\
\text { 2001; 2012 (Phyllocladus } \\
\text { aspleniifolius) } \\
\text { McDougall et al., 2012 } \\
\text { (Podocarpus lawrencei) }\end{array}$ & $\begin{array}{l}\text { Brookhouse and Bi, } \\
\text { 2009; Brookhouse et al., } \\
2008 \text { (Eucalyptus } \\
\text { pauciflora) }\end{array}$ & $\begin{array}{l}\text { Allen et al., } 2012 \\
\text { (Athrotaxis } \\
\text { cupressoides) } \\
\text { Brookhouse et al., } \\
2008 \text { (Eucalyptus } \\
\text { pauciflora) } \\
\text { Drew et al., } 2013 \\
\text { (Lagarostrobus } \\
\text { franklinii) } \\
\text { Allen et al., } 2012 \\
\text { (Phyllocladus } \\
\text { aspleniifolius) }\end{array}$ & $\begin{array}{l}\text { Allen et al., } 2011 \\
\text { (Athrotaxis sp.) }\end{array}$ \\
\hline Arid & $\begin{array}{l}\text { Cullen and Grierson, } \\
2007 \text { (Callitris } \\
\text { columellaris) }\end{array}$ & $\begin{array}{l}\text { Sgherza et al., } 2010 \\
\text { (Callitris sp.) } \\
\text { Cullen and Grierson, } \\
\text { 2007; 2009 (Callitris } \\
\text { columellaris) }\end{array}$ & & \\
\hline Tropical & $\begin{array}{l}\text { Ash, 1983a (Araucaria } \\
\text { cunninghamii) } \\
\text { Baker et al., } 2008 \\
\text { (Callitris intratropica) }\end{array}$ & $\begin{array}{l}\text { Ash, 1983a; Boysen et } \\
\text { al., 2014 (Agathis } \\
\text { robusta) } \\
\text { Ash, 1983a (Araucaria } \\
\text { cunninghamii) } \\
\text { Baker et al., 2008; Drew } \\
\text { et al., 2011 (Callitris } \\
\text { intratropica) } \\
\text { Ash, 1983b (Callitris } \\
\text { macleayana) } \\
\text { Mucha, 1979 (Eucalyptus } \\
\text { sp.) } \\
\text { Heinrich et al., } 2008 \\
\text { (Toona ciliata) }\end{array}$ & & \\
\hline Subtropical & & $\begin{array}{l}\text { Heinrich and Banks, } \\
\text { 2005; Heinrich et al., } \\
2009 \text { (Toona ciliata) }\end{array}$ & & \\
\hline
\end{tabular}




\subsection{Regional applications of dendroclimatology in Australia}

The following section reviews the progress and potential for dendroclimatic study in four major climate regimes across Australia; based upon the Bureau of Meteorology's (BOM)

Climate Classification of Australia (BOM, 2005), specifically the Temperate, Tropical,

Subtropical, and Arid zones. Table 1 provides a list of the Australian tree ring chronologies by region and the most likely environmental variable limiting tree growth. Studies that developed reconstructions are shown in bold. Figure 1 shows the location of these studies.

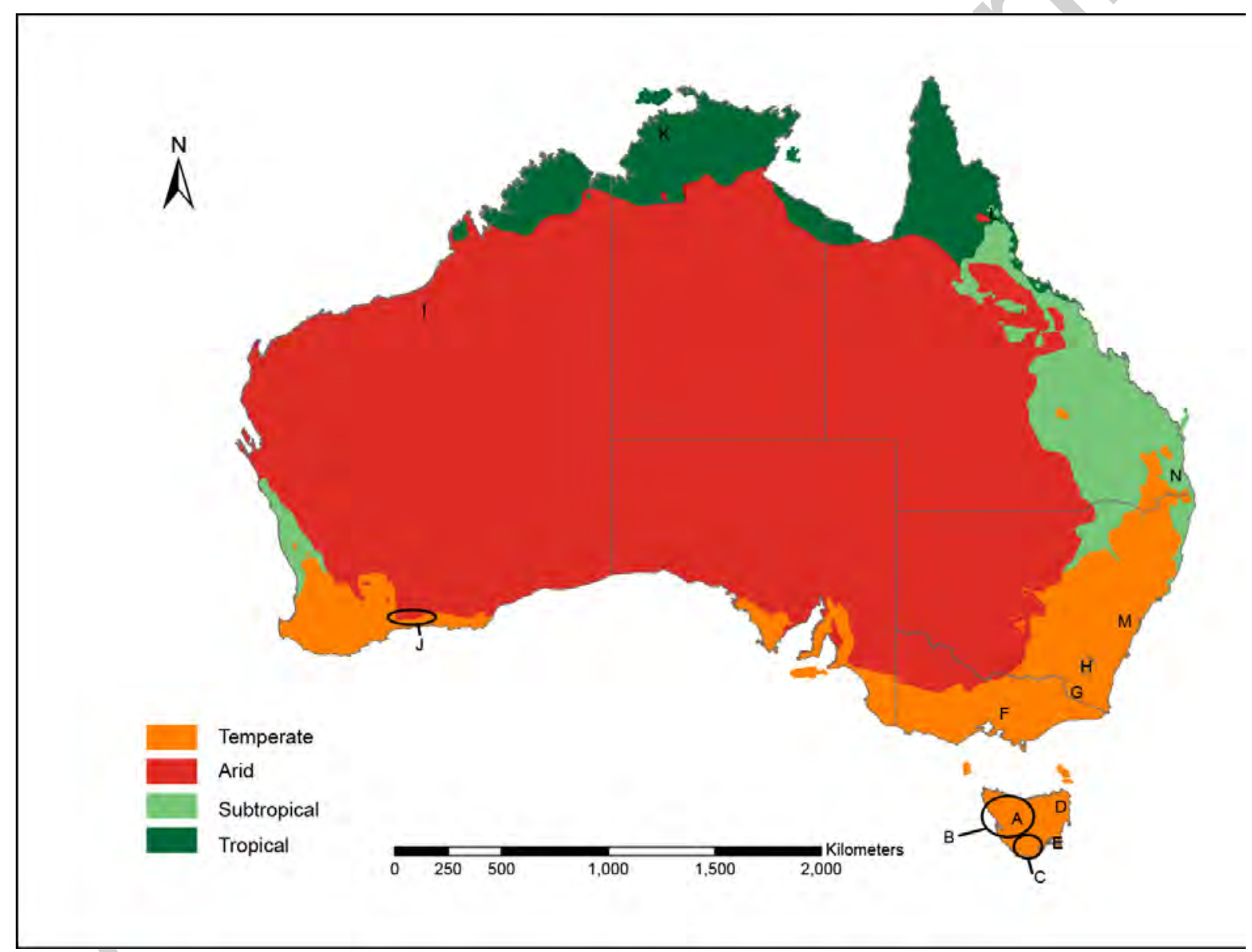

Figure 1: The climate zones of Australia and the locations of the studies reviewed in this paper. The studies associated with each location are A (Mount Read) = Allen et al., 2012; 2013; Buckley et al., 1997; Cook et al. 1991; 1992; 1996; 2000; Ogden, 1978b, B = Allen et al., 2001; 2011; 2012; 2013, Buckley et al., 1997; Drew et al., 2013; Pearman et al., 1976, C = Allen, 2002, Allen et al., 2011; Ogden, 1978a; 1978b, D = Allen et al., 2001, $\mathrm{E}=$ Allen et al., 2001, F = Brookhouse and Brack, 2006; 2008, G = Brookhouse et al., 2008; McDougal et al., 2012, $\mathrm{H}=$ Brookhouse and $\mathrm{Bi}, 2009$; Heinrick and Banks, 2005, I = Cullen and Grierson, 2007, J = Cullen and Grierson, 2009; Sgherza et al., 2010, K = Baker et al., 2008; Drew et al., 2011; Mucha, 1979, L = Ash, 1983a; 1983b; Boysen et al., 2014; Heinrich and Banks, 2006a; Heinrich et al., 2008; Ogden, 1981, M = Heinrich and Banks, 2005, N = Heinrich and Banks, 2006a; Heinrich et al., 2009 


\subsection{Temperate Zone}

The temperate climate zone of Australia includes portions of the coasts and ranges of mainland Western Australia, South Australia, Victoria, and New South Wales, as well as the island state of Tasmania (Figure 1). The earliest instrumental climate records for the temperate region begin in 1832 in New South Wales, with a useful coverage across this zone achieved in the 1850s (BOM 2015).

In the seminal review of Australian dendrochronological research, Ogden (1978a) indicated that the greatest potential exists within Tasmania, which possesses several tree genera that have long-lived individuals as well as ring-width characteristics that are suitable for crossdating. Glacial-interglacial climate and sea-level changes over the Quaternary have led to a high level of endemism in the Tasmanian flora, such that the Tasmanian pine species found there are not present on the mainland. Dendroclimatic study in the temperate zones of the mainland has been less extensive than in Tasmania, owing to early suggestions that Tasmanian species would provide stronger dendroclimatic results. Four Tasmanian pine species were identified as being the most suitable for dendrochronology; namely Athrotaxis cupressoides, A. selaginoides, Lagarostrobos franklinii (L. franklinii; then Dacrydium franklinii, see Molloy, 1995), and Phyllocladus aspleniifolius. Ogden (1978a) suggested that Lagarostrobos franklinii possessed great dendrochronological potential, prompting several researchers to focus on this species. An international research team began studying $L$. franklinii in the late 1980 s, beginning with a millennial length chronology developed from the high elevation (950 m asl) temperate rainforest at Mount Read in western Tasmania (Figure 1; Cook et al., 1991). This research developed a 1089-year record and correlated the growth of the Mount Read trees to November-April (Austral summer) instrumental temperatures records between 1885 and 1989 (Cook et al., 1992). The resulting reconstruction extended from 900 to 1989 and clearly identified years with either cold or warm temperatures outside the normal range. This record is one of the longest annual temperature reconstructions for the Southern Hemisphere (Cook et al., 
1992), as well as the longest dendrochronological record in Australia. Incorporation of subfossil L. franklinii specimens and updated analysis techniques has extended this temperature reconstruction to $1600 \mathrm{BC}$ and improved its quality (Cook et al., 2000). This additional work made the Mount Read $L$. franklinii reconstruction one of the longest reconstructions in the world (see Figure 7; Cook et al., 2000). The existence of this 3592year record allows aspects of Tasmanian temperature to be analysed that was not possible with shorter records. For example, Cook et al. (2000) note that the extent of recent warming since the 1900 s is matched with a period of temperature variability in the tree-ring record prior to $A D 100$, suggesting that the amplitude of recent change may not be anomalous. Cook et al. (1996; 2000) also identified long-term oscillations of 31, 57, 78, and 200 years in the $L$. franklinii temperature reconstruction. The extensive study of $L$. franklinii at Mount Read has exemplified the benefits of persistent research into growth patterns in Australian tree species.

Elsewhere in Tasmania, the effect of elevation on the temperature response of $L$. franklinii was examined from a network of seven $L$. franklinii sites including Mount Read at elevations ranging between 200 and $950 \mathrm{~m}$ asl (Buckley et al. 1997). This showed that, in Tasmania, a threshold exists at $700 \mathrm{~m}$ asl, above which temperature becomes the main limiting factor to growth in L. franklinii. Stands of $L$. franklinii at low elevations in Tasmania were difficult to crossdate and showed little conformity with the temperature response of high alpine specimens (Buckley et al., 1997). These findings provided insight into the environmental growth relationships in L. franklinii and reinforced decisions to prioritize high elevation sites in western Tasmania over lower elevations. However, as indicated by Ogden (1978a), the scarcity of suitable tree species across the various climate regions in Australia, requires dendroclimatic studies to be undertaken on trees in suboptimal locations. Drew et al. (2013) noted some temperature relationships based on wood properties, in this case tracheid radial diameter and microfibril angle, of $L$. franklinii from a low elevation (60 $\mathrm{m}$ asl) rainforest in western Tasmania. Several wood properties were also tested by Allen et al. (2013) using X- 
ray densitometry, with strong correlations to Austral summer regional temperature being observed in both tracheid radial diameter and microfibril angle. This demonstrates the need to use alternate dendrochronological techniques to explore the full potential of Australian species.

The dendroclimatic potential of several other long-lived, temperate pine species in the Tasmanian rainforests have also been investigated. Ogden (1978b) showed that both Athrotaxis cupressoides and Athrotaxis selaginoides were of a useful length and had measureable ring boundaries allowing for the creation of long-term tree-ring chronologies. Pearman et al. (1976) also found a relationship between A. selaginoides and Austral summer temperature through the use of $\delta^{13} \mathrm{C}$. Athrotaxis species proved more challenging to crossdate than $L$. franklinii owing to frequent occurrences of false and missing rings, as well as the presence of frost rings (Ogden, 1978b). However, Athrotaxis species have proved to be better suited for regional scale climate reconstructions than $L$. franklinii, as they are present across a large climatic and geographical range (Allen et al. 2011). Allen et al. (2011) utilized seven Athrotaxis chronologies from across Tasmania to assess the potential for reconstructing several climate variables including temperature, precipitation, and atmospheric oscillation indices. The climate sensitivity observed in Athrotaxis was strongly related to temperature and had very few significant correlations to precipitation or oscillation variables. However, Allen et al. (2011) did notice that there appears to be a link between the Athrotaxis species and drought variables which would make this species useful for inclusion in large scale multi-proxy studies of Australian drought conditions. Attempts to strengthen the climatic signal represented in A. cupressoides in eastern Tasmania have been made by using a limited number of wood density chronologies following evidence of a relationship between wood density patterns and temperature (Allen et al., 2012). This was the first time a wood density relationship had been published in Australia but several studies had found this to be a viable technique for dendroclimatic reconstruction elsewhere in the world (Allen et al., 2012; Briffa et al., 2002; D’Arrigo et al.; 1992; Polge, 1970). The low sample size 
precluded definitive correlations with climate; however, the average wood density values could be reliably crossdated between individual trees and linked to temperature variables as well as to streamflow values which indicates a larger scale study could be used to develop a climate and/or hydrological reconstruction (Allen et al., 2012).

Included in the Allen et al. (2012) wood density study were Phyllocladus aspleniifolius samples from eastern Tasmania which is another species identified by Ogden (1978a) as being of strong dendroclimatic potential. Allen et al. (2001) had previously utilized samples from $16 P$. aspleniifolius sites across Tasmania to determine how growth in this species was related to temperature during the previous growth season. While $P$. aspleniifolius is a shorter lived species it is a strong choice for use in dendroclimatology as it has a large altitudinal and geographical range that covers most of Tasmania (see Figure 1 in Allen et al., 2001). Allen (2002) investigated the potential of an altitudinal (temperature) signal in $P$. aspleniifolius samples from four elevations between 100 and $900 \mathrm{~m}$ asl in the Warra Long Term Ecological Research site in southern Tasmania. They concluded that there was no relationship between altitude/temperature and ring-widths in $P$. aspleniifolius.

In mainland Australia dendrochronological studies have focused heavily on the widely distributed genus Eucalyptus (Brookhouse, 2006). Only a few of the 700 species known to exist in Australia, specifically E. delegatensis, E. obliqua, E. sieberi, E. cypellocarpa, E. baxteri, E. pauciflora, and E. camaldulensis have been targeted. Research was undertaken on montane forest E. delegatensis and E. obliqua trees in the Central Highlands of Victoria (Brookhouse and Brack, 2006). Each species was developed into a separate ring-width chronology and compared to climatic variables which showed significant correlations between average ring width and mean minimum and mean maximum temperatures for the preceding winter in $E$. delegatensis and both the preceding and current summer in $E$. obliqua. This was the first instance in which climate signals were identified in eucalypt ringwidth series supporting the hypothesis of Brookhouse (2006) that eucalypts show 
dendroclimatic potential and should be targeted for study. Brookhouse and Brack (2008) extended this study of eastern Victorian eucalypts looking at the effect of age and site position on ring-widths in four temperate Eucalyptus species; E. obliqua, E. sieberi, E. cypellocarpa, and E. baxteri. Brookhouse and Brack (2006) determined that the first ten years of growth in the species they examined did not show a strong climatic signal.

For a targeted climate reconstruction Brookhouse et al. (2008) located a treeline site on the Kosciuszko plateau of New South Wales at an elevation of about $1800 \mathrm{~m}$ asl that has a representative sample of Eucalyptus pauciflora which were growth limited by climatic conditions. A 31 year chronology from 1963 to 1994 was developed for this alpine treeline site. Ring-width was found to be significantly correlated with temperature prior to and during the current growing season as well as to precipitation in the preceding winter and autumn of the current growing season. To help determine the full climatic conditions of the area ringwidth was compared to snow depth in the preceding winter and spring and a strong negative correlation was observed for all months with snow on the ground. A follow-up study using $E$. pauciflora from the Brindabella Range, along the western boarder of the Australian Capital Territory, was undertaken to determine if this species' climate response was dependent on elevation (Brookhouse and Bi, 2009). Samples were collected at 1350, 1475, and $1600 \mathrm{~m}$ asl and ring-width chronologies were developed that were compared to mean minimum and mean maximum temperatures as well as to precipitation. The high elevation site was significantly correlated with spring mean maximum temperature, the low elevation site to Austral summer precipitation, and the mid-elevation site was not significantly correlated to any climate variables.

More recent work in temperate New South Wales has utilized a non-Eucalyptus species, Podocarpus lawrencei, which is the only alpine conifer found in Australia (McDougall et al., 2012) and is known to form annual rings (Barker, 1991). In the Australian Alps P. lawrencei grows in a lobate stem form which causes ring wedging; consequently to enable crossdating 
full-stem cross-sections were used to develop a 114 year chronology. Significant correlations between growth-rings and spring air temperature as well as winter snow cover were observed. While McDougall et al. (2012) showed the high dendroclimatic potential of $P$. lawrencei they did note that preservation of non-living trees is rare and the need for crosssections for dating is a destructive sampling method reducing the usefulness of this conifer species.

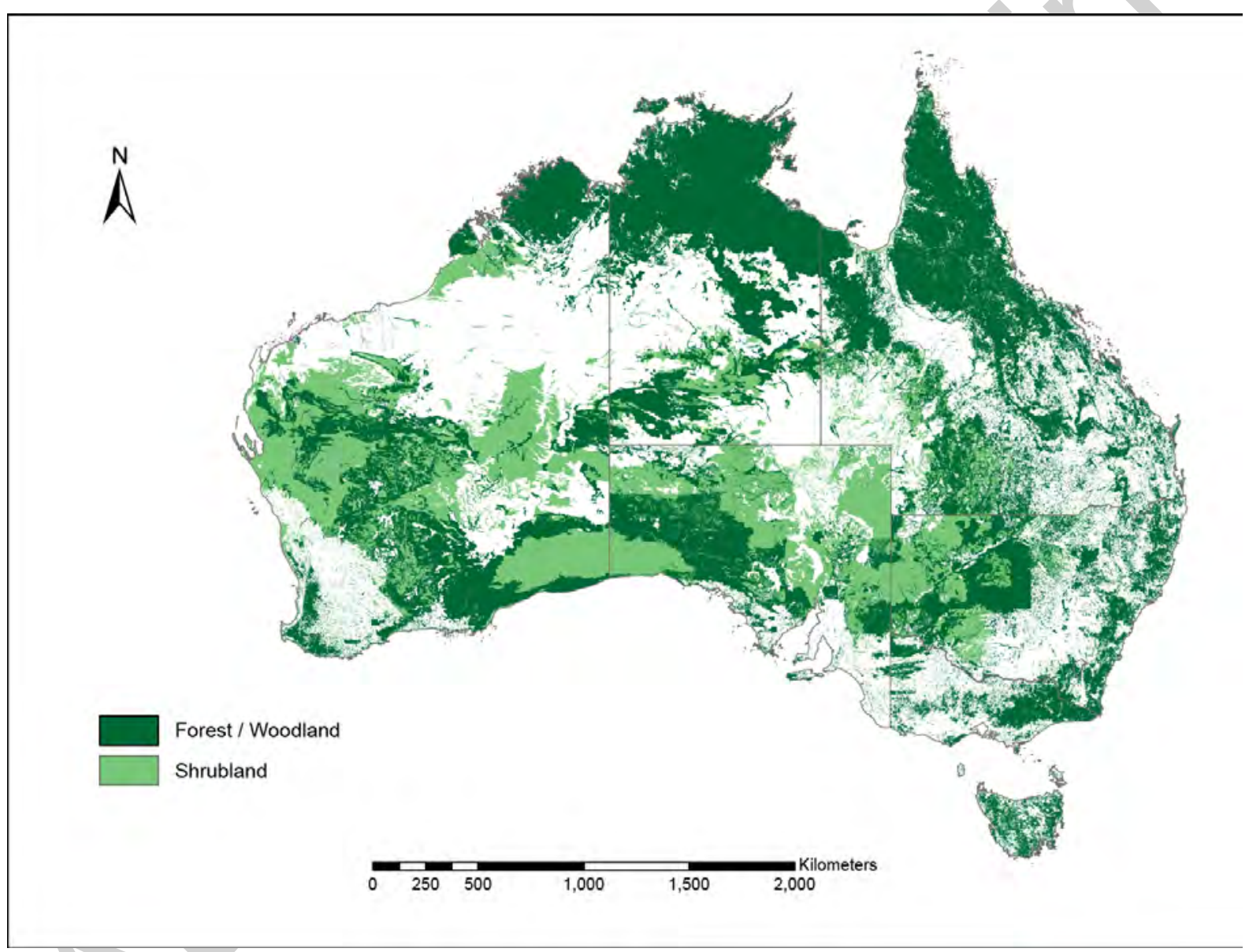

Figure 2: Existing regions of forest and shrubland across Australia.

\subsection{Arid Zone}

The arid zone of Australia is expected to be particularly vulnerable to climate change (IPCC, 2013) and the impact of long-term climatic variability on arid zone species is hypothesized to be significant (Pittock, 2003). In addition, this large geographic area lacks significant longterm instrumental climate records (BOM, 2001). The region contains not only extensive stands of trees but also shrubs (Figure 2), which can be used for dendrochronological 
studies (Speer, 2010). Many of these tree and shrub species demonstrate an annual signal; however, they are often found in dense clusters which can create localized growth effects (Cullen and Grierson, 2007). Fires are also quite common in the arid zone, killing off stands across large areas and making it difficult to locate individuals of sufficient age for long-term study (O'Donnell et al., 2011). Recent work has begun to use dendroclimatology to help understand this vulnerable ecosystem and how it is responding to climate change. Most of this research has involved drought tolerant Callitris species which are well distributed across the arid zone (Bowman and Harris, 1995) and are known to be dependent on precipitation for growth (Ash, 1983b; Bowman and Latz, 1993; LaMarche et al., 1979).

A key dendroclimatic study from the central Pilbara region of Western Australia used isotopic signatures in Callitris columellaris trees to identify climatic variability (Cullen and Grierson, 2007). Isotope chronologies were used as they are better at excluding non-climatic information than ring-width records, allowing for less interference from local factors in climate comparisons (Panek and Waring, 1997; McCarroll and Loader, 2004). Analysis of $\delta^{18} \mathrm{O}$ for the 1919-1999 period demonstrated a strong negative correlation with both summer rainfall and relative humidity and a positive correlation with January - August temperature (Cullen and Grierson, 2007). The authors developed a qualitative reconstruction of climate trends, as opposed to annual climatic values, from 1919-1999 for the central Pillbara. Following on from their qualitative isotopic climate trend reconstruction Cullen and Grierson (2009) developed the first annual ring width rainfall reconstruction in arid Australia for the Lake Tay region of Western Australia. C. columellaris trees were sampled to form a 1654-2005 reconstruction (Cullen and Grierson, 2009). Significant correlation was observed with monthly, seasonal, and annual rainfall values allowing for a March - September rainfall reconstruction to be developed. This reconstruction has a multi-decadal variability in the 350 -year record that highlights periods of above and below average rainfall, with the persistence of dry periods being 5-15 years greater than wet periods (Cullen and Grierson, 2009). A weak but significantly negative correlation to the Southern Oscillation Index was 
also observed in the Lake Tay chronology. Cullen and Grierson (2009) predict that the lowfrequency rainfall variability observed in this rainfall reconstruction is related to the natural variability of El Niño Southern Oscillation (ENSO).

Cullen and Grierson's (2009) Lake Tay C. columellaris chronology was utilized in a truncated form (1871-2005) along with proximal chronologies at two Callitris preissii sites and one Callitris canescens site to look at developing both ring-width and $\delta^{13} \mathrm{C}$ chronologies from the same datasets which have different climate signals and therefore allow multiple climate variables to be reconstructed (Sgherza et al., 2010). All four ring-width chronologies and some of the $\delta^{13} \mathrm{C}$ chronologies showed significant positive and negative correlations to seasonal rainfall variables, respectively. Sgherza et al. (2010) used principal component analysis (PCA) that combined the tree-ring and isotopic chronologies at each site, to reduce the local noise in the signals, in an attempt to develop a stronger climate signal following results reported in studies at other locations (McCarroll and Loader, 2004). The outcome for the isotopic Callitris samples was not encouraging, as a weaker relationship to rainfall was observed in the combined PCA analysis when compared to the ring-width reconstruction alone. Sgherza et al. (2010) suggest that for Callitris trees in arid environments it may be sufficient to focus on developing a long-term ring-width chronology if the desired outcome is a rainfall reconstruction.

The limited dendroclimatological research undertaken on Callitris species in the arid zone of Australia has been successful at showing a link between tree growth and climate in this region. Several other studies have been undertaken on the dendroecological potential and fire histories of these species with some beginning to attempt to link climate interactions with ecological studies (see O'Donnell et al., 2010; 2011). Additionally, several multi-proxy climate reconstructions for Australia have included the Cullen and Grierson (2009) arid zone C. columellaris chronology and several of the major long-term Tasmanian temperate 
chronologies (see Gergis et al., 2012; Mills et al., 2013; Palmer et al., 2015), demonstrating the strength of these dendroclimatic works.

\subsection{Tropical Zone}

The tropical region of Australia is located above $20^{\circ} \mathrm{S}$ latitude and is found in portions of Queensland, the Northern Territory, and Western Australia (see Figure 1). This region encompasses both dry and wet rainforest as well as sections of cloud forest containing many tropical tree species in which growth is known to relate to the climate conditions of the area. Tropical dendrochronology within Australia is poorly studied, however; this topic has generated great interest worldwide in the past two decades (Stahle, 1999; Zuidema et al., 2012). Compared to temperate zone sites, dendroclimatological analysis in tropical locations is more difficult as the majority of tropical tree species do not form a distinct annual growth ring and many produce false and missing rings (Stahle, 1999; Worbes, 2002).

In the late 1970 s and early 1980 s several studies identified some Australian tropical species that had both dendrochronological potential as well as a relationship to climatic variables. Notably, Mucha (1979) investigated three eucalypt species from northern Australia, E. tetrodonta, E. miniata, and E. nesophila. He observed that these tropical eucalypt tree species were not as long-lived as their temperate counterparts, often lost their inner rings to decay and/or insect damage, and required someone with knowledge of dendrochronology and ring characteristics to properly identify annual rings for counting. However, the study results showed that not only were the rings generally identifiable but that growth occurred seasonally with a strong relationship to rainfall. Around the same time Ash undertook two studies (1983a; 1983b) utilizing three other tropical species, Araucaria cunninghamii, Agathis robusta, and Callitris macleayana which he determined to all have annual growth patterns although those of $A$. robusta were sometimes more than annual (Ash, 1983a). Ash (1983a) noticed a relationship to rainfall for both $A$. cunninghamii and $A$. robusta as well as a connection to temperature for the $A$. cunninghamii specimens. In his other study undertaken 
on C. macleayana trees from the Atherton Tablelands in Queensland, Ash (1983b) identified a strong correlation between ring width and wet season duration indicating strong dendroclimatic potential. It was noted however that none of the $C$. macleayana trees from the study site were of sufficient age to extend past instrumental records and that some localized growth effects were observed (Ash, 1983b). Nevertheless, these three studies by Mucha and Ash demonstrated that tropical Australian trees could be used as climate proxies.

Callitris intratropica was the focus of a more recent study by Baker et al. (2008) that developed two chronologies for the Northern Territory, Australia; the first, Howard Springs, spanned 1965-2004 while the second, Pine Creek, covered the period 1847-2006. The two chronologies were of significant quality with inter-series correlation greater than 0.65 in both cases, which was the best correlation for a tropical tree series when reported (Baker et al., 2008). The rejection rates of cores that did not fit into the chronologies were also quite low for a tropical species study. Baker et al. (2008) compared their chronologies to several climate variables and found significant positive correlations to rainfall during the early monsoon (October - December) and the end of monsoon (March - April) seasons. Mean maximum temperature was found to have a significant positive correlation in the Pine Creek record for the Austral winter months (June - September) and a significant negative correlation during December and March. Baker et al. (2008) also compared the Pine Creek chronology to the Palmer Drought Severity Index, a metric used to analyse plant moisture stress, and found a significant positive correlation for the duration of the monsoon and early dry season. These climate relationships indicate that growth in $C$. intratropica in this region is limited by water availability, a fact supported by a similar relationship observed between the Howard Springs chronology and October - December rainfall (see Figure 7 in Baker et al., 2008). Baker et al. (2008) indicate that false and missing rings were observed in several of their cores but that the samples were highly crossdateable making this species viable for further tropical study. This work was furthered by Drew et al. (2011) who looked at the 
seasonal water deficit in C. intratropica in the Northern Territory, Australia and noted a relationship between tree growth and water availability. Additionally, Drew et al. (2011) found that $C$. intratropica was a strong choice for tropical climate reconstruction as growth clearly ceased during the dry season indicating that the ring banding observed in their samples is annual. However, a difference in behaviour was noted between isolated trees and grove trees (those with no and much competition, respectively). Seasonal water deficit was stronger in grove trees where the competitions for water was greater, thus indicating grove trees would be more limited by water stress and therefore represent a better rainfall reconstruction (Drew et al., 2011). Once water stress reached a significant level tree growth was found to cease all together in grove trees. Drew et al. (2011) indicated that a tropical $C$. intratropica chronology sensitive to rainfall conditions would be best developed from a mix of both grove and isolated trees to increase dating accuracy.

Another species that has been studied for climate relationships in the Queensland tropics is Toona ciliata. Heinrich et al. (2008) developed a chronology from this species from 1860 2000 and compared it to monthly and annual climate variables determining that growth in this species was limited by late growth season precipitation. Extreme wet/dry climate anomalies were also noted to relate to growth anomalies in the ring width record. Based on this analysis Heinrich et al. (2008) were able to create the only current rainfall reconstruction for the Queensland tropics which represents 140-years of March to June (late season) rainfall from $1860-2000$. While this reconstruction does not extend much past the instrumental record there is potential to extend it further as tree-ring data exists from 1591 but the sample size is too low before 1860 to confirm the chronology (Heinrich et al., 2008).

Isotopic dendroclimatological analysis has also been undertaken in the tropical zone. Boysen et al. (2014) looked at $A$. robusta samples from the Atherton Tablelands and ran both ring width measurements and $\delta^{18} \mathrm{O}$ analysis on the rings. Boysen et al. (2014) had a lot of difficultly creating a ring width chronology for this site as there were a large number of 
false rings in their samples which made it difficult to identify true annual boundaries.

However, their isotopic analysis on a 15-year composite chronology from two samples was able to identify and date false ring growth in one sample. This suggests that a combination of isotopic and ring width techniques could allow for long-term chronology development if false ring identification could occur. The isotopic $\delta^{18} \mathrm{O}$ composite chronology was also found to be correlated with mean seasonal rainfall further promoting the usefulness of isotopic dendroclimatic study for this tropical species (Boysen et al., 2014) and suggesting that other tropical species may also benefit from similar isotopic study.

\subsection{Subtropical Zone}

The subtropical Australian climate zone is located predominantly on the east coast of Queensland with some representation in the northeastern part of New South Wales and a small region on the west coast in Western Australia (see Figure 1). As with the tropical zone very little dendroclimatological work has been undertaken in the subtropical regions of Australia. The range of species occurring in this zone often overlaps with the tropical and temperate regions but as yet little research has been done to determine if the subtropical zone trees respond similarly to their species counterparts in other climate regions. The only species used for dendroclimatic studies in the subtropics is Toona ciliata (Heinrich et al., 2009). Heinrich and Banks (2005) began researching this species at both a temperate site in the Australian National Botanic Gardens in Canberra and at two subtropical sites in NSW (Robertson and Upper Kangaroo Valley) using dendrometer bands to understand the seasonality of growth. Results from all three sites showed a dormant period in the winter with the majority of growth occurring between mid-December to mid-April and early December and late March for the temperate and subtropical sites respectively. Differences were noted in their climate relationship with growth based on climate zone location, as only temperature was found to be a significant factor in growth at the temperate site but both rainfall and temperature were significant at the subtropical sites. This result indicated that the dendroclimatological potential of $T$. ciliata is dependent on zonal location (Heinrich and 
Banks, 2005). The Upper Kangaroo Valley subtropical site was selected for ring width analysis with a chronology from 1970-2001 to be developed (Heinrich and Banks, 2005).

Climate response in this 31 year chronology indicated that growth preferences in spring were to dry and warm conditions with precipitation becoming important later in the year when soil water reserves had been depleted. High maximum and mean temperatures were also found to cause stress in $T$. ciliata trees as high temperatures limit the moisture available for growth (Heinrich and Banks, 2005). The results from this preliminary study showed that $T$. ciliata is a viable tree for dendroclimatic study but that a greater understanding of the trees growth was needed before a long-term rainfall reconstruction could be developed.

To better understand the wood anatomical structure of T. ciliata Heinrich and Banks (2006a) undertook a study to identify false and missing rings in both the Upper Kangaroo Valley samples as well as new samples from a subtropical site in Lamington National Park in Southeast Queensland. Indistinct ring structures were identified as a feature in these samples causing difficultly in ring boundary identification (Heinrich and Banks, 2006a). In their study Heinrich and Banks (2006a) visually crossdated some of their samples and found that false rings were present. Results from their 2006a paper lead to further analysis of the younger portions of tree-ring series which determined that there was a strong ability in young trees to adapt to variations in environmental conditions (Heinrich and Banks, 2006b). This caused growth patterns to be based on localized and short term conditions which may increase the number of false or missing rings. Heinrich and Banks (2006b) used their study of tree growth variations and phenology to determine that $T$. ciliata is a viable species for dendroclimatic study while noting that care should be taken in site and sample selection to optimize climate sensitivity and reduce age related variations. Such a detailed approach to tree anatomy and growth pattern analysis provided the authors with the ability to work around the difficulties common in tropical and subtropical Australian species. This detailed analysis then permitted further research to develop the first rainfall reconstruction for an Australian subtropical region (Heinrich et al., 2009). 
Twenty dominant and sub-dominant trees in Lamington National Park were used to develop a 146-year (1854-2000) subtropical chronology from T. ciliata (Heinrich et al., 2009). This chronology was then compared to monthly temperature and precipitation data from the Brisbane climate station for the period $1900-2000$ and it was determined that rainfall was the highest correlated variable with an $r^{2}$ value of 0.59 (Heinrich et al., 2009). However, it should be noted that the rainfall stations were about $250 \mathrm{~km}$ from the tree sampling site. This precipitation reconstruction identified five periods of extended drought and four periods of extended wet conditions along with delineating four and six extremely dry and wet years respectively (Heinrich et al., 2009). As this reconstruction fell within the historical period Heinrich et al. (2009) were able to compare the wet and dry events to historical events presented by Whetton (1997) which showed that actual events were well represented by the reconstruction.

\subsection{Discussion}

Analysis of the 36 dendroclimatic studies clearly indicates that each of the four major climate zones of Australia contain tree species which have the potential to provide high quality records of past climate. While the Mount Read Tasmanian temperate zone reconstruction of temperature extending back to $1600 \mathrm{BC}$ (Cook et al., 2000) is currently anomalous within Australia, the arid, tropical, and subtropical zones have only recently begun to be studied in detail suggesting future long-term climate reconstructions are possible on a continental scale. A key development in Australian dendroclimatology is the movement away from a sole reliance on traditional ring width measurements to develop climate reconstructions. More varied research involving isotopic analysis, wood density measurements, and wood anatomy studies have proven useful in extracting dendroclimatic information from species that would have been abandoned in a more traditional approach. A recent review paper by Heinrich and Allen (2013) highlights this in stating that Australian dendrochronology needs to take a different course than just placing a heavy reliance on traditional ring-width 
measurements. They note the numerous non-standard chronologies developed in Australia, many of which are included in this paper, and highlight the need for a multi-technique approach.

Table 2: Australian dendroclimatic studies for which a reconstruction was developed.

\begin{tabular}{|lll|}
\hline \multirow{2}{*}{ Region } & \multicolumn{1}{c|}{ Reconstructed Environmental Variable } \\
\cline { 2 - 3 } Temperate & $\begin{array}{l}\text { Comperature } \\
\text { (Lagarostrobos franklinii) }\end{array}$ & Precipitation \\
\hline Arid & $\begin{array}{l}\text { Cullen and Grierson, 2009 (Callitris } \\
\text { columellaris) }\end{array}$ \\
\hline Tropical & Heinrich et al., 2008 (Toona ciliata) \\
\hline Subtropical & Heinrich et al., 2009 (Toona ciliata) \\
\hline
\end{tabular}

Four dendroclimatic reconstructions have been published for Australia, one from each of the climate zones (Table 2). The most extensive reconstruction of Lagarostrobos franklinii is for Mount Read in western Tasmania which has been reported on in successive iterations with the most detailed chronology presented in Cook et al. (2000). This reconstruction represents warm-season temperature for a 3592-year period from $1600 \mathrm{BC}-1991 \mathrm{AD}$. The relationship between tree-ring width and regional temperature had a correlation coefficient for the calibration period of $r=0.683$ and $r=0.518$ for the validation period. The length of this reconstruction has allowed for the identification of several long-term, multi-decadal as well as century-scale oscillation patterns that are driving climate in the temperate Tasmanian region (Cook et al., 2000). This temperature reconstruction is the longest paleoclimate record found in Tasmania and is also one of the longest dendroclimatic reconstructions in the Southern Hemisphere (Cook et al., 2006). However, Cook et al. $(2000,2006)$ make it clear that they have over 4000 years of tree-ring data but the EPS values and sample size prior to $1600 \mathrm{BC}$ are too low to reliably reconstruct climate.

The other three reconstructions within Australia are not nearly as long as the temperature record from Mount Read. The longest precipitation record is the arid zone Lake Tay Callitris 
columellaris autumn-winter rainfall reconstruction, developed by Cullen and Grierson (2009) which extends for 350 years from 1655 - 2005. The relationship between tree-ring width and regional rainfall had a correlation coefficient of $r=0.7$. It should be noted however that the nearest instrumental record was $\sim 75 \mathrm{~km}$ from the studied site and, had more local records existed, the correlation may have been higher. Again there was a longer record of tree-ring data with cross-dated samples going back to 1601 , but small sample size truncated the reconstruction at 1655 . The record from Lake Tay showed that rainfall for that region has naturally varied over the last 350 years, from relatively dry periods lasting to $20-30$ years, to periods of above average rainfall lasting 15-years. Cullen and Grierson (2009) suggest that this multi-decadal variability relates to a low-frequency ENSO signal. They also suggested that the current sustained decline in rainfall, which began in the 1960 s, that the region is experiencing may be part of the long-term natural variability.

Similar ENSO related signals are observed in the tropical and subtropical Toona ciliata reconstructions developed by Heinrich et al. (2008 and 2009 respectively). The tropical record from the Atherton Tablelands reconstructs late season (March - June) precipitation for 140-years from 1860-2000. The relationship between tree-ring width and rainfall had a correlation coefficient for the calibration period of $r=0.59$ and $r=0.45$ for the validation period. Once again a much longer cross-dated tree-ring series was developed with data extending back to 1591 however, with fewer than five trees representing each year prior to 1860 the EPS value drops below the critical 0.85 threshold (Heinrich et al., 2008). This precipitation reconstruction demonstrated both high and low frequency multi-decadal signals identified by Heinrich et al. (2008) as representing the Interdecadal Pacific Oscillation (IPO) and ENSO signals respectively. This high and low frequency IPO and ENSO variability was also observed in the Toona ciliata annual precipitation reconstruction for subtropical Southeast Queensland (Heinrich et al., 2009). This was also a short-term rainfall reconstruction covering 146-years from $1854-2000$, with a correlation coefficient of $r=$ 0.59. The tree-ring record was correlated with the longest rainfall record in the region which 
was located at the Brisbane City about $250 \mathrm{~km}$ from the study site. Again had a more local record been used the correlation may have been higher. Heinrich et al. (2009) again indicated that the tree-ring record extended back further in time but analysis was limited to the 1854 and later period as the EPS value reached 0.85 at this time.

A clear theme is evident from these reconstructions that low sample size is truncating proxy climate reconstructions that in some cases could extend the reconstruction nearly three times the current length. By focusing on greater long-term replication or selecting other species that are longer lived and have been identified as having dendroclimatic potential there is the ability to create long-term proxy climate records across most of Australia. A recent large-scale undertaking to create a drought atlas for Australia can be found in Palmer et al. (2015) where long-term tree-ring records (as well as one coral record) were used to determine drought conditions across the eastern half of Australia as well as New Zealand. Within this drought atlas the mainland of Australia was highly underrepresented with only five tree-ring chronologies used (see Figure 1 in Palmer et al., 2015). The development of long-term dendrochronological records for inclusion into datasets of large scale climate patterns such as that found in Palmer et al. (2015) is an important undertaking to move forward tree-ring studies within Australia.

Moreover, along with the ability to extend the length of their records, all four existing climate reconstructions demonstrate evidence of long-term natural variability of stable oscillation patterns. This indicates that Australian dendroclimatological reconstructions can be used for assessing how shifts in climate (both temperature and precipitation) relate to both natural and anthropogenic derived variability. For instance in the Mount Read temperature record a period of warming prior to AD 100 is noted as having a similar scale warming trend as is observed since 1900 (Cook et al., 2000). The use of this long-term paleoclimate record indicates that such a trend in warming may be a natural phenomenon yet the general belief is that the post-1900 warming is entirely anthropogenic in design. The ability to identify long- 
term natural variability in climate records is important in understanding current trends and human modifications to environmental conditions. Through the development of long-term tree-ring climate records true natural and modified conditions across Australia can be determined.

The studies covered in this review have demonstrated that the potential exists to produce long-term records of climate in each of the climate zones across the continent. However, there is still a lack of basic knowledge on the relationship between climate variables and tree growth, especially in tropical environments. Rather than working with well-studied and understood species, each Australian study must first assess the targeted species in terms of its growth response to the climate variable of interest. This is one of the reasons that little work has been undertaken in Australia, however, as each new study is completed the ecological knowledge base available to future investigations increases allowing for more paleoclimate knowledge to be developed.

\subsection{Conclusion}

The 36 studies identifying growth-climate relationships covered in this review clearly show that many species in Australia demonstrate dendroclimatological potential and can be used to develop long-term climate reconstructions. Only a fraction of the thousands of tree and shrub species in Australia have been assessed for an ability to provide such long-term paleoclimate data. The four climate reconstructions that do exist for this continent are already providing highly useful data enabling current climate conditions to be assessed against past variability. They are also enabling long-term effects of atmospheric oscillation patterns on the continent to be assessed. Further studies need to develop more climate reconstructions as well as extending records already developed across the Australian mainland. There is a great deal of potential for dendroclimatic research in this country and a critical need to fill in the gaps that currently exist in past climatic understanding. A move away from a sole reliance on traditional ring-width measurements to develop climate 
reconstructions, using more varied techniques such as isotopic analysis, wood density measurements, and wood anatomy should enable more dendroclimatic information to be extracted from species that would have been abandoned in a more traditional approach. 


\section{Conflict of Interest}

The author's declare no conflicts of interest.

\section{Acknowledgements}

Funding for this research has been made possible through an Australian Research Council Linkage Grant

(LP120200093). Heather Haines received PhD scholarships from Griffith University, the Australian Research

Council, and the Australian Institute of Nuclear Science and Engineering. Support was provided by the Griffith

University Postgraduate Student Association editor-in-residence Evie Franzidis. We would like to thank Dr Craig

Woodward and four anonymous reviewers for comments on early drafts of this manuscript.

\section{References}

Allen, K.J., 2002. The temperature response in the ring widths of Phyllocladus aspleniifolius ( $P$. aspleniifolius) along an altitudinal gradient in the Warra LTER area, Tasmania. Australian Geographical Studies, 40(3), 287299. http://dx.doi.org/10.1111/1467-8470.00181.

Allen, K.J., Cook, E.R., Francey, R.J., Michael, K., 2001. The climatic response of Phyllocladus aspleniifolius (Labill.) Hook. f in Tasmania. Journal of Biogeography, 28(3), 305-316. http://dx.doi.org/10.1046/j.13652699.2001.00546.x.

Allen, K.J., Ogden, J., Buckley, B.M., Cook, E.R., Baker, P.J., 2011. The potential to reconstruct broadscale climate indices associated with southeast Australian droughts from Athrotaxis species, Tasmania. Climate Dynamics, 37, 1799-1821. http://dx.doi.org/10.1007/s00382-011-1011-7.

Allen, K.J., Drew, D.M., Downes, G.M., Evans, R., Baker, P.J., Grose, M., 2012. Ring width, climate and wood density relationships in two long-lived Tasmanian tree species. Dendrochronologica, 30, 167-177. http://dx.doi.org/10.1016/j.dendro.2010.12.006.

Allen, K.J., Drew, D.M., Downes, G.M., Evans, R., Cook, E.R., Battaglia, M., Baker, P.J., 2013. A strong regional temperature signal in low-elevation Huon Pine. Journal of Quaternary Science, 28(5), 433-438. http://dx.doi.org/ $10.1002 /$ jqs.2637.

Ash, J., 1983a. Growth rings in Agathis robusta and Araucaria cunninghamii from Tropical Australia. Australian Journal of Botany, 31, 269-275. http://dx.doi.org/10.1071/BT9830269.

Ash, J., 1983b. Tree rings in tropical Callitris macleayana F. Muell.. Australian Journal of Botany, 31, $277-281$. http://dx.doi.org/10.1071/BT9830277.

Baker, P.J., Palmer, J.G., D’Arrigo, R., 2008. The dendrochronology of Callitris intratropica in northern Australia: Annual ring structure, chronology development and climate correlations. Australian Journal of Botany, 56, 311320. http://dx.doi.org/10.1071/BT08040.

Barker, P.D.J., 1991. Podocarpus lawrencei (Hook.f): population structure and fire history at Goonmirk Rocks, Victoria, Australia. Australian Journal of Ecology, 16, 149-158. http://dx.doi.org/10.1111/j.14429993.1991.tb01042.x.

Bowman, D.M.J.S., Latz, P.K., 1993. Ecology of Callitris glaucophylla (Cupressaceae) on the MacDonnell Ranges, Central Australia. Australian Journal of Botany, 43, 217-225. http://dx.doi.org/10.1071/BT9930217.

Bowman, D.M.J.S., Harris, S., 1995. Conifers of Australia's dry forests and open woodlands. In Enright, N.J., Hill, R.S. (Eds) Ecology of the southern conifers. Melbourne University Press, Melbourne, 252-270. 
Boysen, B.M.M., Evans, M.N., Baker, P.J., 2014. $\delta^{18} \mathrm{O}$ in the tropical conifer Agathis robusta records ENSOrelated precipitation variations. PLoS ONE 9(7), e102336. http://dx.doi.org/10.1371/journal.pone.0102336.

Brewer, P., 2014. Data management in dendroarchaeology using Tellervo. Tree-Ring Research, 70: S79-S83. http://dx.doi.org/10.3959/1536-1098-70.3.79.

Briffa, K.R., Bartholin, T.S., Eckstein, D., Jones, P.D., Karlén, W., Schweingruber, F.H., Zetterberg, P., 1990. A 1,400-year tree-ring record of summer temperatures in Fennoscandia. Nature, 346, 434-439. http://dx.doi.org/10.1038/346434a0.

Briffa, K.R., Osborne, T.J., Schweingruber, F.H., Jones, P.F., Shiyatov, S.G., Vaganov, E.A., 2002. Tree-ring width and density data around the Northern Hemisphere: part 1, local and regional climate signals. The Holocene, 12, 737-757. http://dx.doi.org/10.1191/0959683602hl587rp.

Brookhouse, M., 2006. Eucalypt dendrochronology: past, present and potential. Australian Journal of Botany, 54, 435-449. http://dx.doi.org/10.1071/BT05039.

Brookhouse, M., Brack, C., 2006. Crossdating and analysis of eucalypt tree rings exhibiting terminal and reverse latewood. Trees, 20, 767-781. http://dx.doi.org/10.1007/s00468-006-0092-0.

Brookhouse, M., Brack, C., 2008. The effect of age and sample position on eucalypt tree-ring width series. Canadian Journal of Forestry Research, 38, 1144-1158. http://dx.doi.org/10.1139/X07-184.

Brookhouse, M., Lindesay, J., Brack, C., 2008. The potential of tree rings in Eucalyptus pauciflora for climatological and hydrological reconstruction. Geographical Research, 46, 421-434. http://dx.doi.org/ 10.1111/j.1745-5871.2008.00535.x.

Brookhouse, B., Bi, H., 2009. Elevation-dependent climate sensitivity in Eucalyptus pauciflora Sieb. Ex Spreng. Trees, 23: 1309-1320. http://dx.doi.org/10.1007/s00468-009-0372-6.

Buckley, B.M., Cook, E.R., Peterson, M.J., Barbetti, M., 1997. A changing temperature response with elevation for Lagarostrobos franklinii in Tasmania, Australia. Climatic Change, 36, 477-498. http://dx.doi.org/10.1007/97894-015-8905-5_13.

Bunn, A., 2008. A dendrochronology program library in R (dpIR). Dendrochronologia, 26: 115-124. http://dx.doi.org/10.1016/j.dendro.2008.01.002.

Bunn, A., 2010. Statistical and visual crossdating in R using the dpIR library. Dendrochronologia, 28: 251-258. http://dx.doi.org/10.1016/j.dendro.2009.12.001.

Bureau of Meteorology (BOM), 2001. Australia's global climate observing system. Australian Bureau of Meteorology, Melbourne.

Bureau of Meteorology (BOM), 2005. Climate classification of Australia map. http://www.bom.gov.au/jsp/ncc/climate_averages/climate-classifications/index.jsp?maptype=kpngrp\#maps

Bureau of Meterorology (BOM), 2015. Climate Data Online. Last accessed Nov 2015.

(http://www.bom.gov.au/climate/data/).

Cook, E. R., 1985. A time- series approach to tree -ring standardization. Ph.D. Dissertation, University of Arizona, Tucson, $171 \mathrm{pp}$.

Cook, E.R, Bird, T., Peterson, M.J., Barbetti, M., Buckley, B.M., D’Arrigo, R.D., Francey, R.J., Tans, P., 1991. Climatic change in Tasmania inferred from a 1089-year tree-ring chronology of Huon Pine. Science, 253, $1266-$ 1268. http://dx.doi.org/10.1126/science.253.5025.1266.

Cook, E.R., Bird, T., Peterson, M.J., Barbetti, M., Buckley, B.M., D’Arrigo, R.D., Francey, R.J., 1992. Climatic change over the last millennium in Tasmania reconstructed from tree-rings. The Holocene, 2(3), 205-217. http://dx.doi.org/10.1177/095968369200200302.

Cook, E.R., Francey, R.J., Buckley, B.M., D’Arrigo, R.D., 1996. Recent increases in Tasmania L. franklinii ring widths from a subalpine stand: Natural climate variability $\mathrm{CO}_{2}$ fertilisation, or greenhouse warming? Papers and Proceedings of the Royal Society of Tasmania, 130(2), 65-72.

Cook, E.R., Buckley, B.M., D’Arrigo, R.D., Peterson, M.J., 2000. Warm-season temperatures since 1600 BC reconstructed from Tasmanian tree rings and their relationship to large-scale sea surface temperature anomalies. Climate Dynamics, 16, 79-91. http://dx.doi.org/10.1007/s003820050006. 
Cook, E.R., Buckley, B.M., Palmer, J.G., Fenwick, P., Peterson, M.J., Boswijk, G., Fowler, A., 2006. Millennialong tree-ring records from Tasmania and New Zealand: a basis for modelling climate variability and forcing, past, present and future. Journal of Quaternary Science, 21(7), 689-699. http://dx.doi.org/10.1002/jqs.1071.

Cook, E.R., Seager, R., Cane, M.A., Stahle, D.W., 2007. North American drought: Reconstructions, causes, and consequences. Earth-Science Reviews, 81(1-2), 93-134. http://dx.doi.org/10.1016/j.earscirev.2006.12.002.

Cullen, L.E., Grierson, P.F., 2007. A stable oxygen, but not carbon, isotope chronology of Callitris columellaris reflects recent climate change in north-western Australia. Climatic Change, 85, 213-229. http://dx.doi.org/10.1007/s10584-006-9206-3.

Cullen, L.E., Grierson, P.F., 2009. Multi-decadal scale variability in autumn-winter rainfall in south-western Australia since $1655 \mathrm{AD}$ as reconstructed from tree rings of Callitris columellaris. Climate Dynamics, 33, 433444. http://dx.doi.org/10.1007/s00382-008-0457-8.

D'Arrigo, R.D., Jacoby, G.C., Free, R.M., 1992. Tree-ring width and maximum latewood density at the North American tree line: parameters of climatic change. Canadian Journal of Forest Research, 22, 1290-1296. http://dx.doi.org/10.1139/x92-171.

Davidson, N.J., Reid, J.B., 1985. Frost as a factor influencing the growth and distribution of subalpine eucalypts. Australian Journal of Botany, 33, 657-667. http://dx.doi.org/10.1071/BT9850657.

Drew, D.M., Richards, A.E., Downes, G.M., Cook, G.D., Baker, P.J., 2011. The development of seasonal tree water deficit in Callitris intratropica. Tree Physiology, 31, 953-964. http://dx.doi.org/10.1093/treephys/tpr031.

Drew, D.M., Allen, K.J., Downes, G.M., Evans, R., Battaglia, M., Baker, P.J., 2013. Wood properties in a longlived conifer reveal strong climate signals where ring-width series do not. Tree Physiology, 33, 37-47. http://dx.doi.org/10.1093/treephys/tps111.

Fritts, H.C., 1976. Tree Rings and Climate. Academic Press Inc. (London) Ltd., London, 567 pages. http://dx.doi.org/10.1038/scientificamerican0572-92.

Gergis, J., Gallant, A.J.E., Braganzam, K., Karoly, D.J., Allen, K., Cullen, L.E., D’Arrigo, R., Goodwin, I., Grierson, P.F., McGregor, S., 2012. On the long-term context of the 1997-2009 'Big Dry' in South-Eastern Australia: insights from a 206-year multi-proxy rainfall reconstruction. Climatic Change, 111, 923-944.

http://dx.doi.org/10.1007/s10584-011-0263-x.

Graham, N.E., Hughes, M.K., Ammann, C.M., Cobb, K.M., Hoerling, M.P., Kennett, D.J., Kennett, J.P., Rein, B., Stott, L., Wigand, P.E., Xu, T., 2007, Tropical Pacific - mid-latitude teleconnections in medieval times. Climatic Change, 83, 241-285.

Grissino-Mayer, H. D., 2001. Evaluating crossdating accuracy: a manual and tutorial for the computer program COFECHA. Tree-ring research 57(1):115-124.

Guay, R., Gagnon, R., Morin, H., 1992. A new automatic and interactive tree ring measurement system based on a line scan camera. The Forestry Chronicle 68: 138-141. http://dx.doi.org/10.5558/tfc68138-1.

Heinrich, I., Banks, J.C.G., 2005. Dendroclimatological potential of the Australian red cedar. Australian Journal of Botany, 53, 21-32. http://dx.doi.org/10.1071/BT04033.

Heinrich, I., Banks, J.C.G., 2006a. Tree-ring anomalies in Toona ciliata. IAWA Journal, 27(2), 213-231. http://dx.doi.org/10.1163/22941932-90000150.

Heinrich, I., Banks, J.C.G., 2006b. Variation in phenology, growth, and wood anatomy of Toona sinensis and Toona ciliata in relation to different environmental conditions. International Journal of Plant Sciences, 167(4), 831-841. http://dx.doi.org/10.1086/503785.

Heinrich, I., Allen, K., 2013. Current issues and recent advances in Australian dendrochronology: Where to next? Geographical Research, 51(2), 180-191. http://dx.doi.org/10.1111/j.1745-5871.2012.00786.x.

Heinrich, I., Weidner, K., Helle, G., Vos, H., Banks, J.C.G., 2008. Hydroclimatic variation in Far North Queensland since 1860 inferred from tree rings. Palaeogeography, Palaeoclimatology, Palaeoecology, 270, 116127. http://dx.doi.org/10.1016/j.palaeo.2008.09.002 
Heinrich, I., Weidner, K., Helle, G., Vos, H., Lindesay, J., Banks, J.C.G., 2009. Interdecadal modulation of the relationship between ENSO, IPO and precipitation: insights from tree rings in Australia. Climate Dynamics, 33, 63-73. http://dx.doi.org/10.1007/s00382-009-0544-5.

IPCC, 2013. Climate Change 2013: The Physical Science Basis. Contribution of Working Group I to the Fifth Assessment Report of the Intergovenmental Panel on Climate Change. Stoker, T.F., Qin, D., Plattner, G.K., Tignor, M., Allen, S.K., Boschung, J., Nauels, A., Xia, Y., Bex, V., Midgley, P.M. (Eds.). Cambridge Univeristy Press, Cambridge, pp. 1535.

LaMarche, V.C., Holmes, R., Dunwiddie, P.W., Drew, L.G., 1979. Tree-ring chronologies of the Southern Hemisphere 4. Australia. Laboratory of Tree-Ring Research, University of Arizona, Chronology Series V.

Luckman, B.H., Briffa, K.R., Jones, P.D., Schweingruber, F.H., 1997. Tree-ring based reconstruction of summer temperatures at the Columbia Icefield, Alberta, Canada, AD 1073-1983. The Holocene, 7(4), 375-389. http://dx.doi.org/10.1177/095968369700700401.

McCarroll, D., Loader, N.J., 2004. Stable isotopes in tree rings. Quaternary Science Reviews, 23, 771-801. http://dx.doi.org/10.1016/j.quascirev.2003.06.017.

McDougall, K.L., Brookhouse, M.T., Broome, L.S., 2012. Dendroclimatological investigation of mainland Australia's only alpine conifer, Podocarpus lawrencei Hook.f. Dendrochonolgia, 30, 1-9. http://dx.doi.org/10.1016/j.dendro.2011.01.011.

Mills, K., Gell, P., Gergis, J., Baker, P.J., Finlayson, C.M., Hesse, P.P., Jones, R., Kershaw, P., Pearson, S., Treble, P.C., Barr, C., Brookhouse, M.T., Drysdale, R., McDonald, J., Haberle, S., Reid, M., Thoms, M., Tibby, J., 2013. Paleoclimate studies and natural-resource management in the Murray-Darling Basin II: unravelling human impacts and climate variability. Australian Journal of Earth Sciences, 60, 561-571. http://dx.doi.org/10.1080/08120099.2013.823463.

Molloy, B.P.J., 1995. Manoao (Podocarpaceae), a new monotypic confier genus endemic to New Zealand. New Zealand Journal of Botany, 33(2), 183-201. http://dx.doi.org/10.1080/0028825X.1995.10410483.

Morrow, P.A., LaMarche, Jr, V.C., 1978. Tree ring evidence for chronic insect suppression of productivity in subalpine Eucalyptus. Science, 201, 1244-1246. http://dx.doi.org/10.1126/science.201.4362.1244.

Mucha, S.B., 1979. Estimation of tree ages from growth rings of eucalypts in northern Australia. Australian Forestry, 42, 13-16. http://dx.doi.org/10.1080/00049158.1979.10674201.

Neukom, R. and Gergis, J., 2012. Southern Hemisphere high-resolution palaeoclimate records of the last 2000 years. The Holocene 22, pp.501-524. http://dx.doi.org/10.1177/0959683611427335

O'Donnell, A.J., Cullen, L.E., McCaw, W.L., Boer, M.M., Grierson, P.F., 2010. Dendroecological potential of Callitris preissii for dating historical fires in semi-arid shrublands of southern Western Australia. Dendrochronologia, 28, 37-48. http://dx.doi.org/10.1016/j.dendro.2009.01.002.

O'Donnell, A.J., Boer, M.M., McCaw, W.L., Grierson, P.F., 2011. Climatic anomalies drive wildfire occurrence and extent in semi-arid shrublands and woodlands of southwest Australia. Ecosphere, 2, 127. http://dx.doi.org/10.1890/ES11-00189.1.

Ogden, J., 1978a. On the dendrochronological potential of Australian trees. Australian Journal of Ecology, 3 , 339-356. http://dx.doi.org/10.1111/j.1442-9993.1978.tb01184.x.

Ogden, J., 1978b. Investigations of the dendrochronology of the genus Athrotaxis D. Don (taxodiaceae) in Tasmania. Tree Ring Bulletin, 38, 1-13.

Ogden, J., 1981. Dendrochronological studies and the determination of tree ages in the Australian tropics. Journal of Biogeography, 8(5), 405-420. http://dx.doi.org/10.2307/2844759.

Palmer, J.G., Cook, E.R., Turner, C.S.M., Allen, K., Fenwich, P., Cook, B.I., O’Donnell, A., Lough, J., Grierson, P., Baker, P., 2015. Drought variability in the eastern Australia and New Zealand summer drought atlas (ANZDA, CE 1500-2012) modulated by the Interdecadal Pacific Oscillation. Environmental Research Letters, 10(12).

Panek, J.A., Waring, R.H., 1997. Stable carbon isotopes as indicators of limitations to forest growth imposed by climate stress. Ecological Applications, 7, 854-863. http://dx.doi.org/10.2307/2269438.

Pearman, G.I., Francey, R.J., Fraser, P.J.B., 1976. Climatic implications of stable carbon isotopes in tree rings. Nature, 260, 771-773. http://dx.doi.org/10.1038/260771a0. 
Peel, M. C., McMahon, T. A., Finlayson, B. L., 2004. Continental differences in the variability of annual runoffupdate and reassessment. Journal of Hydrology, 295(1), 185-197. http://dx.doi.org/10.1016/j.jhydrol.2004.03.004

Pittock, B., 2003. Climate Change: An Australian guide to the science and potential impacts. Australian Greenhouse Office, Canberra.

Polge, H., 1970. The use of X-ray densitometric methods in dendrochronology. Tree Ring Bulletin, 30, 1-10.

Seager, R., Graham, N., Herweijer, C., Gordon, A.L., Kushnir, Y., Cook, E., 2007. Blueprints for Medieval hydroclimate. Quaternary Science Reviews, 26, 2322-2336.

Sgherza, C., Cullen, L.E., Grierson, P.F., 2010. Climate relationships with tree-ring width and $\delta^{13} \mathrm{C}$ of three Callitris species from semiarid woodlands in south-western Australia. Australian Journal of Botany, 58, 175-187. http://dx.doi.org/10.1071/BT09222.

Speer, J. H., 2010. Fundamentals of tree-ring research. University of Arizona Press, 333 pp.

Stahle, D.W., 1999. Useful strategies for the development of tropical tree-ring chronologies. IAWA Journal, 20, 249-253. http://dx.doi.org/10.1163/22941932-90000688.

Stokes, M.A., Smiley, T.L., 1968. An Introduction to Tree-ring Dating. University of Arizona Press, Tucson, AZ, 73 pages.

Wheeton, P., 1997. Flood, droughts and the Southern Oscillation connection. In: Webb E.K. (ed), Windows on meteorology: Australian perspective. CSIRO Publishing, Melbourne, pp 180-199.

Wigley, T.M.L., Briffa, K.R., Jones, P.D., 1986. On the average value of correlated time series with applications in dendroclimatology and hydrometeorology. Journal of Climate and Applied Meteorology, 21, 201-213. http://dx.doi.org/10.1175/1520-0450(1984)023\%3C0201:OTAVOC\%3E2.0.CO;2.

Wilson, R.J.S., Luckman, B.H., 2005. A 500 year dendroclimatic reconstruction of spring-summer precipitation from the lower Bavarian Forest region, Germany. International Journal of Climatology, 25(5), 611-630. http://dx.doi.org/10.1002/joc.1150.

Worbes, M., 2002. One hundred years of tree-ring research in the tropics - a brief history and an outlook to future challenges. Dendrochronologia, 20(1-2), 217-231. http://dx.doi.org/10.1078/1125-7865-00018.

Zuidema P.A., Brienen, R.J.W., Schöngart, J., 2012. Tropical forest warming: looking backwards for more insights. Trends in Ecology and Evolution 27, 193-194. http://dx.doi.org/10.1016/j.tree.2011.12.007 